\title{
A Participatory Culture for Developing an Inclusive Environment in Higher Education
}

\author{
Dhyah Ayu R. Widyastuti ${ }^{1}$, B.K. Prihandono ${ }^{2}$, A.B. Pramudyanto ${ }^{3}$, L.A. Rudwiarti ${ }^{4}$ \\ ${ }^{1}$ Department of Communication Science, Universitas Atma Jaya Yogyakarta, Indonesia \\ (email: dhyah.ayu@uajy.ac.id) \\ 2) Department of Sociology, Universitas Atma Jaya Yogyakarta, Indonesia \\ ${ }^{3}$ Department of Communication Science, Universitas Atma Jaya Yogyakarta, Indonesia \\ ${ }^{4)}$ Department of Architecture, Universitas Atma Jaya Yogyakarta, Indonesia
}

\begin{abstract}
Increasing understanding, concern, partiality, and equality for persons with disabilities is important. One disparity can be found in the educational area. The role of the government to increase the capability of this group is the enactment of Law No. 8 of 2016, which substantially provides accessibility to persons with disabilities. The education environment needs to participate in building a disability-friendly education climate. This paper presents a higher education case study for students with special needs at Universitas Atma Jaya Yogyakarta. The research uses the Inclusive Participatory Action Research approach to explore problems, design program planning, management, and implementation of efforts to create a disability-friendly environment. Through this approach, persons with disabilities are the subject of planning, implementation, and evaluation. It means that the active involvement of the target group is essential in this effort. The results show that participatory culture is essential in building an inclusive environment in higher education. The commitment and cooperation of all university members can realize a disabilityfriendly environment. The focus of this article includes (a) efforts to build a disability-friendly environment; (b) disability-friendly education approach; (c) challenges in the implementation and environmental impacts of inclusion in higher education. Hopefully, this idea can contribute to building an inclusive environment in an educational institution.
\end{abstract}

\section{Keywords:}

disability; higher education; inclusive environment; participatory culture

\section{Introduction}

The disability issue has become a public's increasingly discussed subject at Indonesian and the world levels. Various laws and regulations in Indonesia have directed various parties to be more inclusive of disabilities. The Law on Disabilities No. 8 of 2016 has further strengthened the mainstreaming of disability issues. Individuals with disabilities have the right to social protection, as stated in the United Nations Convention on the Rights of Persons with Disabilities (UNCRPD).

The data of persons with disabilities in Indonesia based on the Management
Information System for Persons with Disabilities is 209,604 individuals (Ministry of Administrative Reform and Bureaucratic Reform., 2021), and the number of students with disabilities who join higher education has grown every year (Arini, 2020). Besides having access barriers, persons with disabilities also experience a high risk of inequality. According to data from the National Team for the Acceleration of Poverty Reduction, Indonesia's number of people with disabilities is significant. These people with disabilities have to struggle for their lives (Larasati et al., 2019). Besides, according to Cameron, L., 
\& Suarez (2017), even in meeting primary education level, children with disabilities are less likely to be compared to children without disabilities.

Citizens with disabilities have the same rights to obtain an education at various types and levels. Law No. 8 of 2016 about Persons with Disabilities explicitly states that persons with disabilities have the right to education. The right to education for persons with disabilities is related to obtaining a quality education in academic units in all types, pathways, and education levels inclusively.

To fulfil the rights of persons with disabilities in obtaining a quality education in tertiary institutions, the government has issued several implementing regulations, including Regulation of The Minister of Research, Technology and Higher Education of The Republic of Indonesia number 46 of 2017 about Special Education and Special Services in Higher Education. Through the regulations, the government expects more opportunities for individuals with disabilities to pursue higher education. This condition is related to the achievement of democracy for every citizen in Indonesia. It meant that inclusive education and the development of democracy are related; this is due to inclusive practice supporting the redistribution of quality opportunities to learn and participate in educational programs (Stepaniuk, 2019; Waitoller, F. R., 2013).

There are barriers to inclusive education, especially in higher education. Stepaniuk's research (2019) showed several stereotyped concepts of people with disabilities. This is also exacerbated by various problems including lack of statistical data on the population of children with disabilities, lack of teacher training, lack of resources in school-related access and accommodations, and lack of government policies related to policy and government. These barriers look like those Indonesia faced (based on International Labour Organization Report, 2013).
Fernandez (2021) explores the intersection between digital technology and disability in higher education. Using the term "Digital Collaborative Making", Fernandez invites students to devise creative methods of criticizing digital technology's social and cultural impact. Regarding the use of technology in education, using the website in a university environment must have accessibility for all academics, including students with disabilities. For example, students with visual impairments can use screen readers and keyboards to access websites, deaf students can access voice services, and others (Arini, 2020).

Becoming an inclusion-based public service is difficult. One school in Malang, Indonesia, has implemented an inclusive education system since 2009. However, they are still limited in providing services to students due to limited competent human resources in this field (Ediyanto et al., 2021). Besides infrastructure and human resources in higher education, another challenge is that it leads to the problem of completing studies. Students with disabilities have relatively lower completion rates than other students. Several factors that need to be considered to trigger their enthusiasm include peer support, disability services, faculty teaching, campus climate, and self-advocacy (Fleming, A.R., Anthony J. Plotner, 2017). The availability of resources and a shift towards a universal learning design will eliminate or reduce the impact of obstacles in realizing inclusive schools (Toutain $\AA$, 2019).

The previous research studies from Garzón Díaz \& Goodley (2021), show that disability studies have pedagogical challenges in the education world and offer productive possibilities. Teaching disability presents several difficulties for both teachers and students, not least in introducing alternative conceptions of disability in direct contrast to the prevailing knowledge practices in our own and students' academic settings. This research 
suggest that we need to develop critical disability theories.

Our research presents a participatory approach as critical research to the majority understanding of disability. Unlike previous research studies, there has been no discussion on the importance of participatory culture in building a disability-friendly environment. This research uses Inclusive Participatory Action Research to describe disability by recognizing the barrier and limitations of every individual in the learning process. Every student participated in identifying their strength and weakness both physically and mentally. Our research uses a different methodology from previous research, such as Tobbell et al. (2021), which explored students' subjective experiences of inclusion in a UK university. They explored what inclusion means to students. Their methodology involved short interviews targeted at personal feelings and experiences. They argue that a prerequisite for an inclusive environment is understanding what inclusion means.

Participatory culture is essential in building a disability-friendly environment. O'Donnell et al. (2012) found a complex process of cultural change within higher education towards inclusive practices. O'Donnell et al. suggest that shifting learning and teaching practices within the university environment becomes a step-by-step process as community members work together to develop a new set of essential techniques and new members are inoculated into those practices.

In Indonesia, several state universities have facilitated the needs of students with special needs, such as UIN Sunan Kalijaga Yogyakarta, Universitas Brawijaya, Politeknik Negeri Jakarta, Universitas Negeri Surabaya (Harususilo, 2020). Some services for students with special needs include vocational education programs in graphic design, crafts, arts, and computer applications. In addition, there are special admission services for people with disabilities, disability service center, scholarships, training, and special fostered programs.

This paper is based on the Universitas Atma Jaya Yogyakarta (UAJY) case, one private university in the Special Region of Yogyakarta province, Indonesia. As a private university with organizational values of excellence, inclusion, humanism, and integrity, UAJY has opened an inclusive education system by accepting students with disabilities since 2017. So far, the learning process continues to be pursued to suit the needs of students in the classroom. Innovations ranging from introducing inclusive education, identification of children with special needs, curriculum development, teaching methods, learning media, lecturer competencies, assessment to academic and non-academic services continue to be improved.

Besides, UAJY was one of 28 universities in Indonesia selected to participate in "Implementation of Special Need Learning Innovation in Higher Education", organized by the Ministry of Research, Technology and Higher Education of Indonesia in 2019. This program aims to accelerate efforts to improve the quality of education services for students with disabilities in universities and encourage the innovation of lecturers in implementing higher education. UAJY in 2020 and 2021 was also selected to implement the same program.

The existence of students with disabilities presents a challenge for institutions to serve infrastructure according to the needs and conditions of students. Importantly, with the COVID-19 outbreak that occurred at the end of 2019, most universities in Indonesia shifted to online learning. There are 58 universities had changed their courses to the online method (Ashari, 2020). This condition poses more challenges for universities to create a disabilityfriendly higher education climate, especially in learning.

This article describes universities' efforts to build a participatory culture to create an 
inclusive environment by implementing an inclusive design in higher education, the required equipment for an inclusive environment, including ICT, and the challenges of building a disability-friendly environment in higher education. Besides, the study's uniqueness is Inclusive Participatory Action Research, which involves students with a disability as a subject in identifying their problems and creating problem-solving. It is hoped this idea contributed to providing an overview of the built-in process, realizing an environment of inclusion in higher education.

\section{Inclusive Environment in Higher Education}

The basic concepts used in this idea depart from an understanding of learning. Following the higher education curriculum, the definition of learning is the process of student interaction with lecturers and learning resources in a learning environment. In universities, there are several communities of people with disabilities. Even though they have much experience, it differs from that experience formed in students in general. This awareness of the presence of disabled students helps their community in university develop an inclusive campus and support students, staff, and lecturers to care more about disabilities. Here, inclusive learning means the availability of accessibility and carrying capacity for people with disabilities in the learning process.

The interaction process can be developed in higher education by creating an inclusive environment. The disability interaction model is shown in Figure 1.

This inclusive environment provides new mobility that emphasizes the academic situation, the success of students with disabilities, and how they can enjoy being in a disabilityfriendly campus (Disability Friendly Colleges, 1998). According to Burgstahler (2008), there are various components to create an inclusive learning environment. The carrying capacity of mobility for people with disabilities includes (a) Classrooms. This is related to the classroom atmosphere, allowing group interaction and collaboration between inclusive students. (b) Classroom design, where ideally there is a space that supports interaction. (c) Furniture requires the availability of furniture that includes a comfortable size, furniture and equipment to accommodate tall and small people (Goldstein, 2008). (d) Restroom, which has the accessibility to rest areas for persons with disabilities. (e) Information and technology resources, related

Figure 1.

Disability Interaction Model

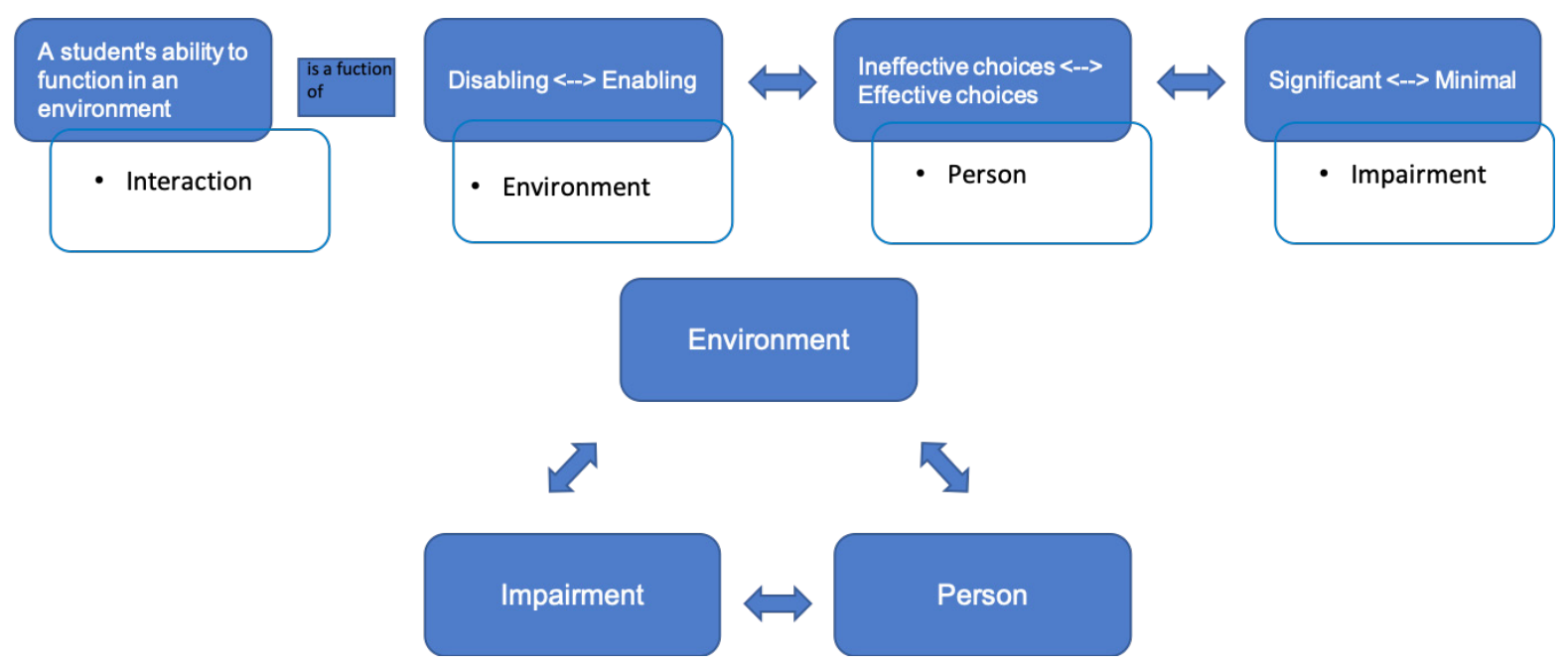

Source: Evans, N. J., E Broido, 2011 
to access to technology, are placed in a range appropriate to student characteristics. (f) Safety and accommodation.

A campus environment accommodating disabilities provides space and dynamic interactions for the carrying capacity involved. This environment is shown in Figure 2.

\section{Figure 2.}

\section{Multidimensional Model of Disability} Identity

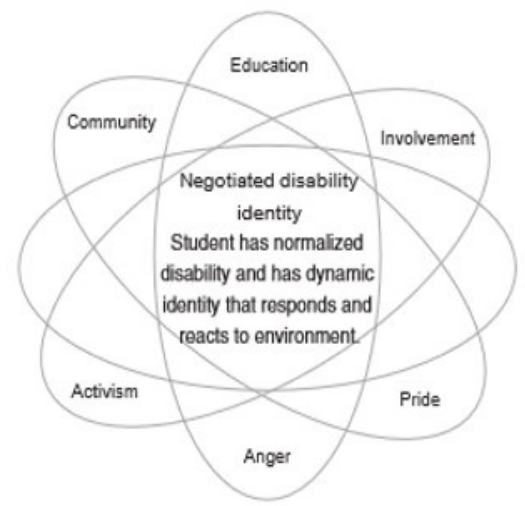

Source: Kraus, 2008

In a deeper thought, to meet the needs of higher education in organizing an inclusive environment, it should be based on the theory of culturally relevant disability pedagogy. Based on this theory, the learning model is directed at inclusive classroom interactions where the capabilities of inclusive students are used as benchmarks in building patterns of learning climate interactions. Following Goodley (2016), a culturally relevant disability pedagogy perspective can be an alternative to inclusive classroom development by orienting the learning process as "social". In this sense, learning orientation is not on individual abilities but collective abilities. The orientation is the development of "potential group possibilities," where the culture and educational atmosphere in the classroom are social constructions of students and lecturers in an equal relationship.

For the development of emancipatory communication, a class based on "weaknesses" and "advantages", following Vygotsky (1978) thought, requires "Re-Mediation", namely new symbols (including language, signs, tools, media) capable of creating equality and eliminating discrimination. These signs, symbols or new media constitute a new language capable of creating "deliberative democracy" spaces in the classroom. A space that can eliminate discrimination, the shortcomings of the definable body to become inclusion.

\section{Methods}

This research is qualitative. Researchers used Inclusive Participatory Action Research (IPAR) to solve problems at UAJY. The researchers use IPAR considering the dynamics of the issue, which is a merger of two things, namely inclusive and Participation Action Research. On that basis, as referring to Ollerton (2012), it is known as IPAR. Action research is not a method or procedure but a series of commitments to observe and solve problems through the practice of social principles McTaggart (1994). This means that through IPAR, activities are carried out in a participatory manner among target groups or a more comprehensive social sphere (especially inclusion groups) to encourage transformative actions through jointly designed programs. The involvement of the target group is the main thing; they are not objects but subjects who can explore problems in their community, design solutions and be involved in implementing activities.

The researcher chose a case from UAJY, a private campus in the Special Region of Yogyakarta province, Indonesia, which, based on the Ministry of Education and Culture ranking in 2020 at the national level, is at number 38 (Anjani, 2021). For private campuses in Yogyakarta, UAJY is in the $3^{\text {rd }}$ place. UAJY has values: Excellence, Inclusive, Humanist, and Integrity. UAJY accepts students from various regions with diverse cultural and 
religious background. In 2017, UAJY accepted students with special needs as an effort to uphold this inclusive value. UAJY was chosen because it is a university that initiated and pioneered inclusive education, especially for people with disabilities. The case raised is related to how the efforts to develop inclusive education are elaborated through the courses in the Departement of Sociology.

The subject of research took classes for students with special needs, including classes in the Department of Sociology, especially the Participation Action Research (PAR) course and the Department of Communication Science, the subject is Computer Communication Program. The case study's emphasis differs between the two study programs.

Participatory Action Research course is chosen because this course practices principles and methods with a participatory approach. This course aims to develop students' ability to be sensitive to social problem situations, deep understanding, and use the perspective of the social group being researched. This course is made thematic by seeing and understanding disability by involving deaf students and their communities invited to this lecture. There are three (3) deaf students in this course class as members of the class (participants).

Computer Communication Program is a course related to using computer program applications. This course is conducted in a computer laboratory with creative thinking as its foundation. Students learned about computer applications that are generally conducted individually with minimal collaboration. However, in this lecture, students are encouraged to collaborate in working on projects. A deaf student is in the class, and a sign language interpreter is still needed. There is a deaf student in this course class as member of the class.

The stages of implementing the activities include

(1) Identifying students' problems with disabilities. At this stage, a needs assessment is carried out to determine the issues and needs of students with disabilities in the learning process. The researchers collected data through a Focus Group Discussion, which aim to obtain data on the needs of students with disabilities more generally by involving students participating in the class. After that, the researchers dug the data by in-depth interviews with students with disabilities.

(2) Building a participatory action program. Researchers involve students with disabilities to create program plans relevant to their needs.

(3) Designing a joint movement to build a disability-friendly education environment. The researcher invites class members, including other academics such as lecturers, office staff, to be sensitive to the needs of students with disabilities. These activities involve language training, providing infrastructure, and other supporting requirements. Besides, it also collaborates with external organizations such as the Tutup Ngisor Community to build a disability-friendly environment. The researchers also held discussions with experts in disability learning development, namely the Wahana Inklusif Indonesia. The involvement of external stakeholders aims to obtain the proper insight in developing the design of learning programs for students with special needs.

(4) Creating a relevant learning model for higher education students. The learning model developed for this study includes two types, namely the "culturally relevant disability pedagogy" innovation model and the "ICT for Disability" innovation model.

The research process was carried out in stages, starting from situation analysis, compiling relevant programs to action research in the form of implementation in the learning process. Through this stage, it is hoped that 
each process in building a disability-friendly environment will be easier to monitor and evaluate.

In this study, the researchers did the observations technique of data collection to strengthen the data by observing the implementation of IPAR in students with disabilities class. Interviews were also conducted with class participants and lecturers to discover the evaluation results in implementing the learning model for students with special needs.

Qualitative data analysis was carried out using an interactive model formulated by Miles, M.B. and Huberman (1994), including data collection, data reduction, data presentation, and conclusion drawing. The steps taken at this stage are that the researcher records and records all the data objectively. Then summarize, choose the main things, focus on the essential things following the research objectives, and present the data. The final step is to verify or draw conclusions based on data reduction and data presentation results to answer the problem formulation or research objectives.

\section{Results}

To support the realization of inclusive classes, universities need a paradigm shift in viewing disability. Researchers see that inclusive human development requires a change in the perspective of the internal and external community on disability issues. Disability issues cannot only be a limitation or functional barriers, such as barriers to visual function (blindness), obstacles to hearing and speech functions (deaf), obstacles to physicalmotor functions (impaired), emotional and behavioural disorders, spectrum disorders, autism, and others. Disability also talks about functional limitations and environmental constraints. The researcher describes the research subjects' efforts in building a disabilityfriendly environment, ICT as a support for the learning system, and the obstacles in implementing the learning process.

\section{Overview of the Environment at UAJY}

UAJY does not explicitly have a Disability Service Unit, and various disability support services are handled in each faculty. The coordination of student functions and cooperation handle the students with disabilities. There are also accesses for disabled people attempted by UAJY to support the educational process. Several facilities are available to meet the general needs of persons with disabilities at UAJY, from ramps in each building and elevators to multimediasupported learning classes.

Ideally, all facilities should have implemented a universal design to allow accessibility for all users, including disabled people, and it is useable by all people, to the greatest extent possible, with no adaptation or specialized design (Widyastuti \& Subejo, 2020). Accessibility is a condition for people with disabilities to realize equal opportunity in various aspects of life, and this is one of the eight principles in the United Nations Convention on the Rights of Person with Disability (Yusril, 2020). UAJY gradually strives to provide facilities that meet the required standards, even though the quantity is limited. Universal design at the campus is one of the essential factors in the operation and good service of higher education (Harahap et al., 2019).

Figure 3.
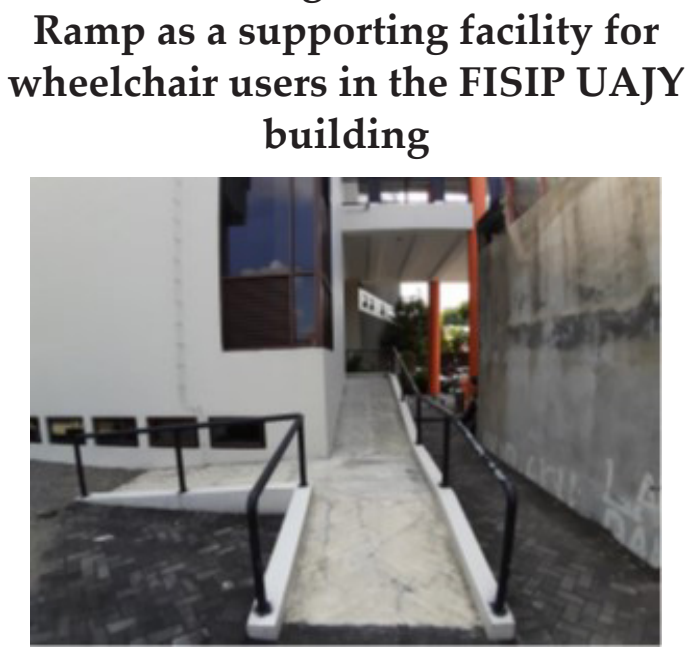

Source: Authors documentation, 2019 
An overview of the inclusive learning process at UAJY has started at the Faculty of Social and Political Sciences (FISIP). The analysis of the learning process related to the learning climate in the classroom is still relatively equal to all students. The interaction with students with special needs is mostly carried out by lecturers, while the sensitivity of other students is still limited. When viewed from the aspect of the physical environment, various facilities are available to accommodate the needs of students with special needs, but in the learning environment, especially in the classroom, there are no supporting facilities relevant to their needs.

\section{Figure 4.}

\section{Classroom}

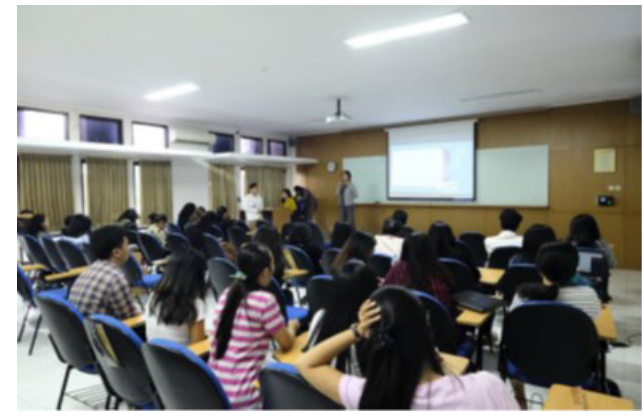

Source: Authors Documentation, 2019

The university has designed educational services for students with special needs by building a discourse on disability issues. It has also carried out discourses on disabilities through various forums, including academic forums in several units, such as the Communication Study Forum on August 16, 2016, with the topic "Communication and Persons with Disabilities". This discourse has also contributed to various other activities that raise issues of disability, like the Radio Show event with the theme "Silentfest Radio Dialogue and Deaf", which was held on November 6, 2016, by the Atma Jaya Radio Student Activity Unit. In May 2019, a conference in the theme "The Importance of an Inclusive Campus for Deaf at UAJY" was held at UAJY. One of the deaf students currently studying at the Faculty of Social and Political Sciences initiated this conference.

\section{Disability-Friendly Environment of UAJY}

The Innovative Learning Model developed by Universitas Atma Jaya Yogyakarta in building a disability-friendly environment includes two types, namely the "culturally relevant disability pedagogy" innovation model and the "ICT for Disability" Innovation Model.

\section{a. Culturally Relevant Disability Pedagogy Model}

The university holds an innovation development model based on culturally relevant disability pedagogy using the IPAR method, Inclusive Participatory Action Research. The students' participatory development methods in building culture, creating new symbols, signs, media, and languages that can expose the ideology of discrimination, and become an emancipatory language of communication. This model was developed in the Participation Action Research class. The students practise IPAR in several stages: 1) discussion about eliminating discrimination communication models; 2) investigating the root causes of discrimination; 3) define an inclusive class; 4) creating symbols, signs, language, and new media; 5) visioning and designing inclusive Teaching Learning Process classes and models; 6) designing monitoring and evaluation models; 7) reflection of inclusive class.

The first model developed is that participants must be aware of exposing the ideology in the mindset that all people have disabilities. For example, when people do not use glasses, they are also disabled. The model of this learning is not class knowledge transfer, but participatory, realizing that body can solve problems to create what solutions are needed to build an inclusive classroom and communicate effectively without using verbal words so deaf people can also understand. That is why in 
PAR classes, participants also learn Indonesian sign language. Lecturers in PAR course are also beginners in using sign language, meaning that the lecturer is not limited to teaching but also learning. Furthermore, in classroom practice, the first thing developed for learning is not only for students with special needs but also for all participants.

Second, identify the sensitivity of human resources in UAJY, especially the Faculty of Social and Political Sciences. Lecturer resources are not competent and still with limited ability, so it is necessary to keep trying to learn. Lecturers who carry out the pilot project are also still learning together and exploring the possibilities that occur during the learning process. Also, non-academic resources such as general office staff are not maximum, but empathy is then built to build communication with students and with definite solidarity - the description of the learning atmosphere in the classroom, as shown in Figure 5.

\section{Figure 5.}

\section{The Atmosphere of the PAR Class with Seating Position Adaptations}

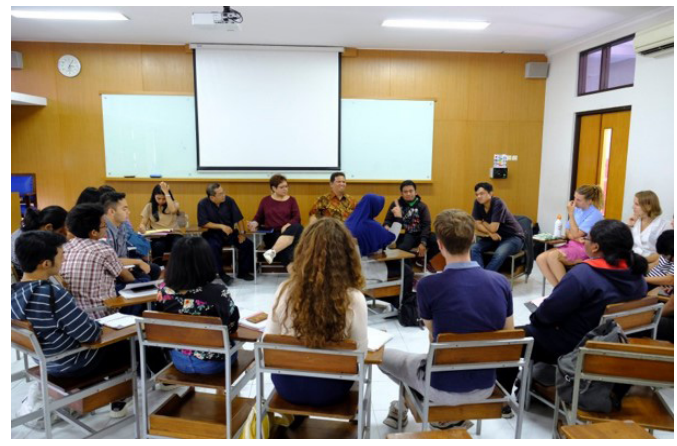

Source: Authors documentation, 2019

Figure 5 shows the atmosphere of the Participatory Action Research class involving Department of Sociology students and exchange students from Germany and the Netherlands. The role of students with special needs can liven up the class, so the lecturer invites other students to be inclusive in the actual application-for example, offering to present assignments to students. Interestingly, students with special needs often raise their hands to present their assignments. This raises enthusiasm for other students because students with special needs are challenged to be able to present.

\section{b. ICT for Disability Model}

Besides building a disability-friendly environment, using ICT helps students with special needs to achieve equality in higher education services. The ICT for Disability model developed at UAJY refers to the concepts of Kalivoda, K.S., Totty, M. C., \& Higbee (2009), including (a) the use of ICT to record lectures that are deaf-friendly. (b) Use and develop access to television or films by displaying translation in sign language on a screen. (c) Using various applications or software to create online inclusive spaces as an application of the concept of remediation so that all participants have equal communication. (d) Creation of new languages, signs and symbols as inclusive communication media, programs that provide online dictionary spelling (thesaurus) functions.

The development of this model is carried out in the Computer Communication Program course. The teaching and learning process in this course seeks to improve its accessibility, especially for people with disabilities. One of its forms is the availability of instructional videos that allow class participants to repeat explanations and tutorials given by the lecturer optimally. The effort to make this video tutorial departs from the problems, differences in understanding and mastery of information and communication technology from each class participant.

In practice, this learning video also still has weaknesses. Based on discussions and input from students with special needs as deaf class participants, the video material still needs to improve the quality to accommodate those who are deaf. Through a discussion process with the primary target audience (deaf students), the lecturer tries to explore 
opportunities to develop instructional videos. From the process of further brainstorming, considering the aspects of accessibility and effectiveness, a solution emerged, that tutorial videos require subtitles so that students can carry out independent learning.-

Figure 6.

\section{Dynamics of sign language interpreters} in the Computer Communication Program class who helps deaf students in the Departement of Communication Science

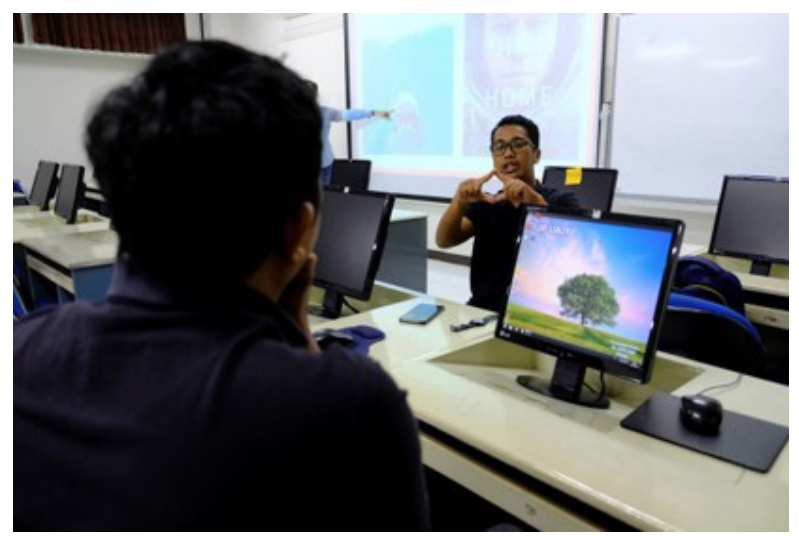

Source: Authors documentation, 2019

The lecturers' sensitivity and willingness to conduct assessments and dialogue with class participants with disabilities is the key to finding simple beneficial solutions for implementing an inclusive class. Lecturers become more aware that subtitles can be very helpful for those with special needs, that is, deaf students.

\section{Implementation of Participatory Culture}

Developing participatory culture through a learning model for students with special needs in the UAJY environment is unique. Based on the description of the two pilot project classes, the specifics of each can be identified, both for the Participation Action Research course and the Computer Communication Program course. a. Participatory Action Research Course

In the PAR class, the efforts made to build an inclusive class are by building an emancipatory learning model, building communication for those having vulnerabilities, who are excluded. The uniqueness of the model offered is to build a communication model that can liberate deaf people, which means freeing everyone to build communication. Participation can build effective communication (Yani \& Yunus., 2017). It means that the class tries to reduce the lecture process, which usually tends to be verbal or speech explanations and replace it with body language and nonverbal communication. Body language is used to seek communication possibilities to overcome body barriers. The focus is on exploring new communication possibilities where deaf people can communicate better with their peers and vice versa. Through this process, each can bypass communication barriers, minimizing discrimination and marginalizing class participants.

The concept of body participatory in this course is developed by the learning process beyond the general learning process in the classroom. In the final section, the Participatory Action Research course explores learning through the practice of body arts to build inclusive and participatory classes. All participants, both internal and exchange students, both deaf and 'hear' students, are invited to be involved in the final project in the form of a visual presentation of body exercises on exploring social, economic, and environmental problems in Tutup Ngisor. Participatory Action Research practices carried out in locations around the slopes of Merapi are reported in physical and movement demonstrations by each group of students participating in the class. This activity is in partnership with Tjipta Boedaja Art Center in Tutup Ngisor, Sumber Village, Magelang Regency. 


\section{Figure 7.}

Students are performing body and movement performances as part of Inclusive Participatory Action Research

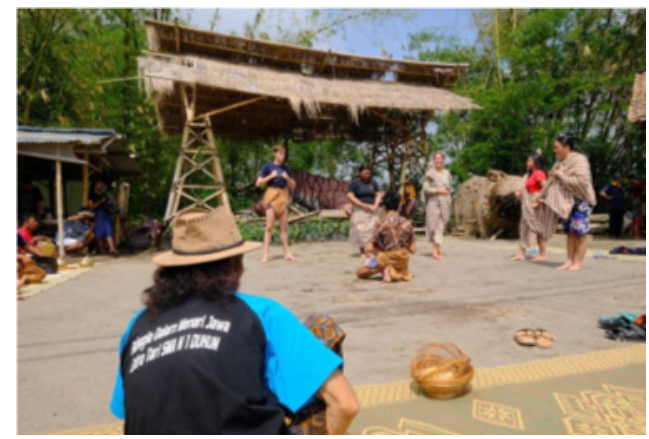

Source: Authors documentation, 2019

\section{b. Computer Communication Program Course}

The model's specificity developed in this class is the learning method by practising directly with computers and learning using videos. Besides that, another peculiarity is the use of sign language, which other students also practice. Although many student learning works are individual, there are efforts to collaborate, and the lecturer builds each class by providing equal space for all class participants to ask questions, present results, and so on.

For example, students with special needs, such as deaf students, have a high initiative to ask questions and present their learning results. When students with special needs present their learning results, the entire class tries to appreciate them by clapping their hands loudly. This response shows a form of appreciation in the language of most class participants, namely those who are "listening" or non-disabled. The lecturer took the opportunity to explain that the majority who are non-disabled also need to learn a language for a deaf disability, namely sign language. All class participants finally understand straightforward sign language, how to clap their hands. Due to this activity, the Deaf felt more appreciated, not only from their work but also from the form of recognition of sign language as part of a form of sign vocabulary recognized in class.

Students are invited to explore learning materials through various visual art practices and experiments. Visual art exploration presents visual artist Made Bayak, who explores used plastic labels or packaging into art. The exploration of visual arts is carried out in groups, where these group work practices encourage students to communicate and interact with one student and others. The practice of communication and interaction helps to liven up the class and open intercultural communication, both in the context of the diverse students' backgrounds from which students come to Deaf culture and Hearing culture.

Figure 8.

\section{Visual creation using plastic packaging}

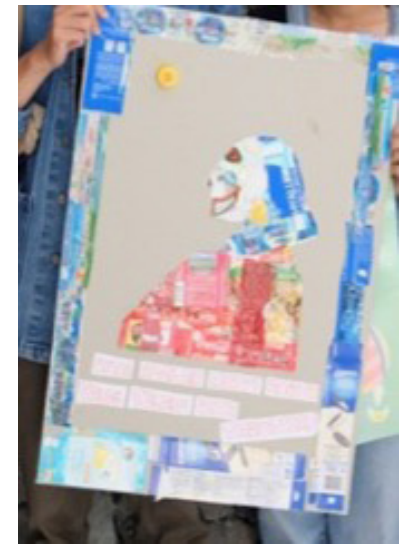

Source: Authors documentation, 2019

The dynamics found in implementing the students with special needs' class underpin the improvements and changes to prepare the curse design, including the Student Center Learning (SCL) model applied. The course design is reviewed and improved by adjusting the values and spirit of inclusion. One of them is using the material in the form of video by looking at the suitability of class conditions which also consists of general students and students with special needs. 


\section{Discussion}

In the practice of inclusive participatory action research, researchers do not fully follow methodological concept but also develop creativity and innovation based on problembased methods.

The Participatory Method encourages each student to identify the limitations of everyone, transforming them into one organism that co-exists in shared learning practices. We elaborate on the concept of Deleuze (1987), in which the practice of inclusive learning is always in the process of becoming. The process of becoming refers to re-organizing how the body is given meaning. Deleuze's concept of 'the fold' undoes a binary opposition between "ability" and "dis-ability", "Deaf" and "Hear". Thus, students realize that diffability and the body are always dynamic, they cannot just be separated by deaf and hearing, but everything mingles, forms, or becomes something "new".

With the inclusive participatory action research method, class transformation occurs when all students realize that disability is not only an individual limitation but can also be a collective one. So, building a culture of inclusive learning means building a systemic organism in which the atmosphere and social relations can overcome the limitations of the individual's body.

Several obstacles occur in creating an inclusive environment in higher education. According to the case study at UAJY, the main obstacle is building awareness to change the understanding of special needs and then the dependence on lecturers. So far, the learning process still relies on lecturers in providing material. However, students can have ideas to make discussions with other themes and issues. As an example, developed in the PAR course, there is no exam like other courses. An evaluation carried out is a joint discussion, self-assessing, where the focus is choosing independently. Because it is under the participatory model, everyone sees the process themselves. This way is an innovation in overcoming obstacles in the inclusive class.

This inclusion class model is a new thing; another obstacle that arises is how to uncover people's awareness of disability. If we reflect, we are actually part of the disability itself. The obstacle is to concretize relevant communication models. This model is difficult because, in this condition, there are obstacles that come from ordinary people from birth and do not feel deprived. However, if we examine, we also have a lot of "special needs".

When viewed from a technical aspect, the class learning process is twice as timeconsuming as the learning process in general. In this context, supporting parties are needed to help students with special needs, a sign language interpreter and language typist. Here, because not everyone has the same language skills, English, Indonesian and sign language. In the communication aspect, language is crucial and often becomes an obstacle. The description in the PAR class is that there are three kinds of students, one with a deaf disability, then foreigners from Germany and the Netherlands as exchange students who are joining in PAR course class, and Indonesian students who are non-disabled. The obstacle to using three languages, English, sign language and Indonesian, is a real communication problem.

Another obstacle is the innovation of the learning model, which looks for alternatives to communication, exploring. So, various possible communication models besides oral language will be developed, namely body language, written language, and visual language.

\section{The Importance of Participatory Culture}

Higher education institutions must find innovative ways to prepare lecturers as facilitators in a culture of participation. To create a culture of equality which means "becoming", here all individuals, both students and lecturers, must have the awareness 
that all participants have "weaknesses" and "advantages". Exploring these weaknesses and strengths is the basis for creating a culture of inclusion, which is not only tolerant but also collective or participative in the philosophy of inclusive education, the creation of an inclusive culture in applying an emancipatory communication culture. Participatory culture describes the role and active participation in the production, dissemination, and interpretation of culture by individuals from a particular community (Jenkins \& Ito, 2016).

There are many subjects involved to realize this effort, namely pilot-project lecturers, students with special needs, other students, and other support systems. By implementation in PAR course, the process is carried out from the beginning in a participatory manner, that is, the involvement of all students. The results can be seen from the participatory evaluation, where they have more wealth not only knowledge of art methods but also experience of differences, solidarity, and empathy. At the same time, even implementation can be seen from the enthusiasm of international students who also have empathy not only with those who cannot speak English but also for those who use sign language.

The efforts to build an inclusive environment can support lecturers to become agents of change, even if only minor changes are initiated in their classes. However, these small changes can become policies that can be developed and sustainable for other classes to follow (McKay et al., 2014).

In addition to implementing inclusivebased learning in the classroom, it is also essential to conduct an initial evaluation of the learning process. Evaluation is carried out on the internal process of each lecturer according to the learning process in class. The real picture in program implementation is seeing how the learning process in the classroom is running. For example, the class becomes less dynamic and less interactive when students with special needs do not enter, but the delivery of material in the class feels fast. The lecturer who implemented the pilot project saw this as a question for them, "Is this inclusive class learning process slow?" Because it takes a long time to deliver the material and it becomes a challenge for lecturers to produce the right model in the learning process.

As a basis for finding the ideal learning model in the PAR course, the social theory of the body where discrimination starts from is the essential foothold. Based on this theory, liberation also begins with the body. The initial assumption is that (1) The more people know the differences, the better the communication model will be; (2) When facilities or inclusive learning materials support an atmosphere of an inclusive learning model, it is furthermore essential to break down the process in understanding how the body's role as a language in building environmental sensitivity. The stages start from trying and searching, identification, solutions, and methods.

The importance of involving other actors is to explore ideas to create conducive interactivity in the classroom. The scheme begins with the team conducting brainstorming, which departs independently to realize and reflect on themselves against the targets. The hope is to dismantle normal and abnormal ideologies. Then empathize, imagining what it would be like if it happened to us, meaning if we were the ones feeling that the body is not to be discriminated against but rather as an understanding of differences. This process forms the basis of emancipation. The more people can identify the problems faced, the body, the more relevant alternative learning models can be. It is hoped this step can also find methods used in the learning process.

Another form of participation is collaborating with the community at Padepokan Tutup Ngisor. This collaboration is to create an innovative model in a communication learning model that can develop for everyone. 
The method developed is to learn about body language, identify that the body has deficiencies, identify solutions, and identify which networks can be invited to work together to implement ideal solutions in the learning process in an inclusive environment.

Participation of several components provides benefits for developing the learning process, including (a) Fostering a democratic atmosphere, (b) Learning process becoming dynamic, filling in the gaps between the participants with one another; (c) Creating a place of mutual respect, there is no domination between the majority and the minority, but they empathize with each other; (d) The resources used to become more efficient because each tries to use the available resources to develop together in creating a conducive learning climate in the inclusive class.

The existence of an inclusive environment in higher education positively impacts students with special needs. An inclusive environment can increase self-efficacy for students with special needs. As with Bandura's concept (1997, in Wangid, M.N., A. Mustadi, 2020), self-efficacy is a cognitive process that produces decisions, beliefs, and rewards about how far individuals estimate their ability to carry out specific tasks or actions needed to achieve the desired results. Based on the research findings, there is an exciting reality of students with special needs; that if they do not have selfconfidence, they would have committed suicide a long time ago. From infancy to adulthood, they are in conditions with different abilities; they always feel minor and discriminated. The existence of an inclusive environment will increase self-confidence and can open space for inclusion for all. Even from the implementation at UAJY, students with special needs appear dominant in the class dynamics that take place.

Based on the Multidimensional Model of Disability Identity (Kraus, 2008), individuals can live in various dimensions of disability. It is indistinguishable from one environment to another to see how they interact and influence one another. Individuals as persons with disabilities react to the environment and are also agents of development for themselves in a dynamically changing environment. In this case study that disability interaction (Evans, N. J., \& Broido, 2011) is an ideal model reference for creating an inclusive environment. The interaction between the environment, people and students with special needs happen. The synergy of each element will have a better impact on the inclusion environment.

\section{Conclusion}

Education is a basic right for every citizen, including people with disabilities, so they can continue to access the world of education. However, building a disabilityfriendly environment is full of challenges. The dynamics of learning is always growing, open, so flexibility and openness are needed from the learning process to produce something more useful, especially in its implementation using a participatory process. The involvement of experienced experts in building inclusive classes is essential to strengthening basic concepts in understanding something new and its applied aspects. Here, learning by doing becomes part of the process to build a learning model.

The description of a case study conducted at Universitas Atma Jaya Yogyakarta in building an inclusive environment using IPAR found several limitations, such as (1) The IPAR concept was carried out with several improvisations in implementing the method; (2) There are still limitations for teachers in developing relevant learning innovations for students; (3) Efforts to build a participatory culture are still at the primary level, so integration and follow-up are needed.

A participatory culture applied to building an environment of inclusion in higher education makes the classroom more democratic. On the other hand, the lecturers 
and student also learn and understand each other better. Students with special needs, lecturers, and other learning participants also learn together. It means there is a democratic culture and a passion for learning. The main thing is as part of being a participatory form in an inclusive environment. ICT users who can create attractiveness and an atmosphere pleasant in the learning process and develop methods and computer applications to build inclusion spaces add to the effectiveness in realizing inclusive classrooms.

\section{Acknowledgement}

Directorate General of Learning and Student Affairs

Ministry of Research, Technology, and Higher Education

\section{References}

Anjani, A. (2021). 5 Universitas Swasta Terbaik di DI Yogyakarta versi Kemendikbud 2020. (5 Best Private Universities in DI Yogyakarta version of the Ministry of Education and Culture 2020). https://www.detik.com/ edu/perguruan-tinggi/d-5655051/5universitas-swasta-terbaik-di-diyogyakarta-versi-kemendikbud-2020.

Arini, F. D. (2020). How Accessible the University Websites in Indonesia for People with Disabilities. Indonesian. Journal of Disability Studies (IJDS), 7(2), 164-169.

Ashari, M. (2020). Data: 58 Perguruan Tinggi di Indonesia Ubah Metode Belajar, Jumlah Bisa Bertambah. www.pikiranrakyat.com/ pendidikan/amp/pr--01351622/data-58 perguruan-tinggi-diindonesia-ubahmetode-belajar-jumlahbisa-bertambah

Burgstahler, S. E. (2008). Universal Design of Instruction: From Principles to Practice. In S. E. Burgstahler \& R. C. Cory (Eds.), Universal Design in Higher Education: From Principles to Practice (pp. 23-43). Harvard University Press.
Cameron, L., \& Suarez, D. C. (2017). Disability in Indonesia: What Can We Learn From The Data. Monash University.

Deleuze, G., \& G. F. (1987). A thousand plateaus: Capitalism and schizophrenia (Brian Massumi, Trans). University of Minnesota Press.

Disability Friendly Colleges. (1998). New Mobility.

Ediyanto, Aris Setiawan, Irvan Budi Handaka, Nurul Hidayati Rofiah, S. (2021). Implementation of Inclusive Education in Learning Process at Senior High School Malang City, Indonesia. Indonesian Journal of Disability Studies, 8(1), 179-189.

Evans, N. J., \& Broido, E. M. (2011). Social Involvement and Identity Involvement of Students with Disabilities. Poster presented at the Association for the Study of Higher Education conference, Charlotte, NC.

Fernandez, S. (2021). Making space in higher education: disability, digital technology, and the inclusive prospect of digital collaborative making. International Journal of Inclusive Education, 25(12), 1375-1390. https://doi.org/10.1080/13603116.2019.161 0806

Fleming, A.R., Anthony J. Plotner, K. M. O. (2017). College Students with Disabilities: The Relationship Between Student Characteristics, the Academic Environment, and Performance. Journal of Postsecondary Education and Disability, 30(3), 209-221.

Garzón Díaz, K. D. R., \& Goodley, D. (2021). Teaching disability: strategies for the reconstitution of disability knowledge. International Journal of Inclusive Education, 25(14), 1577-1596. https://doi.org/10.1080 /13603116.2019.1640292

Goldstein, E. (2008). Applications of Universal Design to Higher Education Facilities. In S. E. Burgstahler \& R. C. Cory (Eds.), Universal design in higher education: From principles to practice (pp. 199-212). Harvard University Press. 
Goodley, D. (2016). Disability Studies: An InterDisciplinary Introduction. 2nd Edition. Sage.

Harahap, R.M., I. Santosa, D. Wahjudi, W. M. (2019). Implementation of Universal Design Concept on Lecture Space for Students with Hearing Disabilities. Indonesia Journal of Disability Studies, 6(2), 193-201.

Harususilo, Y. E. (2020). 4 Kampus Negeri di Indonesia Ini Bisa Diikuti Sahabat Difabel. https://edukasi.kompas.com/ $\mathrm{read} / 2020 / 02 / 04 / 21212571 / 4-k a m p u s-$ negeri-di-indonesia-ini-bisa-diikutisahabat-difabel?page=all

International Labour Organization Report. (2013). Inklusi Penyandang Disabilitas di Indonesia. https://www.ilo.org/jakarta/ whatwedo/publications/WCMS_233426/ lang--en/index.htm

Jenkins, H., M. Ito, danah B. (2016). Participatory Culture in a Networked Era: A Conversation on Youth, Learning, Commerce, and Politics. John Wiley \& Sons. https://books.google. co.id/books?id=AHfiCgAAQBAJ\&pg=P $\mathrm{T} 10 \&$ source $=g b s \_t o c \_r \& c a d=4 \# \mathrm{v}=$ onepa ge\&q\&f=false.

Kalivoda, K.S., Totty, M. C., \& Higbee, J. L. (2009). Appendix E: Access to Information Technology. In J. L. Higbee \& A.A. Mitchell (Eds.), Making Good on The Promise: Student Affairs Professionals with Disabilities (pp. 226-232). American College Personnel Association and University Press of America.

Kraus, A. (2008). The Sociopolitical Construction of Identity: A Multidimensional Model of Disability (Doctoral dissertation). University of Arizona, Tucson.

Larasati, D., Huda, K., Cote, A., Rahayu, S.K., \& Siyaranamual, M. (2019). Ringkasan Kebijakan: Perlindungan Sosial Inklusif Bagi Penyandang Disabilitas di Indonesia [Policy Brief: Inclusive Social Protection for Persons with Disabilities in Indonesia]. Sekretariat Tim Nasional Percepatan Penanggulangan Kemiskinan.
McKay, L. M., Carrington, S., \& Iver, R. (2014). Becoming an Inclusive Educator: Applying Deleuze \&amp; Guattari to Teacher Education. Australian Journal of Teacher Education, 39(3). https://doi. org/10.14221/ajte.2014v39n3.10

McTaggart, R. (1994). Participatory Action Research: issues in theory and practice. Educational Action Research, 2(3), 313-337. https://doi.org/10.1080/0965079940020302

Miles, M.B. and Huberman, A. . (1994). Qualitative Data Analysis, Second Edition. SAGE Publication.

Ministry of Administrative Reform and Bureaucratic Reform. (2021). Wujudkan Masyarakat Inklusi Indonesia Dengan Sinergi Seluruh Komponen Bangsa. (Realizing an Inclusive Indonesian Society with the Synergy of All Components of the Nation). https:// menpan.go.id/site/berita-terkini/dariistana/wujudkan-masyarakat-inklusiindonesia-dengan-sinergi-seluruhkomponen-bangsa.

O’Donnell, V. L., Tobbell, Jane, Bradshaw, C. and Richmond, E. (2012). Participation in inclusive learning and teaching practices in higher education : a qualitative study of academic staff identity and change. International Journal of Technology and Inclusive Education (IJTIE), 1(2).

Ollerton, J. (2012). IPAR, An Inclusive Disability Research Methodology with Accessible Analytical Tools. International Practice Development Journal, 2(2), 1-20.

Stepaniuk, I. (2019). Inclusive education in Eastern European countries: a current state and future directions. International Journal of Inclusive Education, 23(3), 328352. https://doi.org/10.1080/13603116.20 18.1430180

Tobbell, J., Burton, R., Gaynor, A., Golding, B., Greenhough, K., Rhodes, C., \& White, S. (2021). Inclusion in higher education: an exploration of the subjective experiences of students. Journal of Further and Higher 
Education, 45(2), 284-295. https://doi.org/ 10.1080/0309877X.2020.1753180

Toutain $\AA$, C. (2019). Barriers to Accommodations for Students with Disabilities in Higher Education: A Literature Review. Journal of Postsecondary Education and Disability, 32(3), 297-310.

Vygotsky, L. S. (1978). Mind in Society: The Development of Higher Psychological Processes. Harvard University Press. https://books.google.co.id/books?hl= en\&lr=\&id=Irq9131EZ1QC\&oi=fnd\&p $\mathrm{g}=\mathrm{PR} 13 \&$ ots $=\mathrm{Hb}$ AoD8zonb\&sig=rAl QDz5JJ5uhoHpcqnhFXxACKrQ\&red ir_esc $=\mathrm{y} \# \mathrm{v}=$ onepage\& $\mathrm{q} \& \mathrm{f}=$ false.

Waitoller, F. R., and E. B. K. (2013). Working in Boundary Practices: Identity Development and Learning in Partnerships for Inclusive Education. Teaching and Teacher Education, 31, 35-45.
Wangid, M.N., A. Mustadi, S. E. B. M. (2020). The Exploration of Teachers' Efficacy in Teaching: Comparative Study in Indonesia and Malaysia. Jurnal Cakrawala Pendidikan, 2(39), 257-298.

Widyastuti, D.A.R., S. (2020). Probing into the Development Communications for Disability Communities in Indonesia. International Journal of Innovation, Creativity and Change, 13(8), 646-664.

Yani, A.A., A.Y. Yunus., M. I. L. (2017). Participation Dynamics of Voters Using ID Card in Local Elections: A Case Study of the 2015 Local Election in South Sulawesi. Jurnal Ilmu Sosial Dan Ilmu Polit, 21(1), 41-56.

Yusril, A. N. (2020). E-Accessibility Analysis in User Experience for People with Disabilities. Indonesia Journal of Disability Studies, 7(1), 106-109. 